negatives were loaned the writer by Professor T. Wingate Todd, director of the anatomical laboratory of Western Reserve University, where Professor Van der Stricht was a guest for some time during the war.

It was understood that profits from the sale of the slides should go for the benefit of the Archives de Biologie. of which Professors Van der Stricht and Brachet are editors. Concerning the Archives Professor Van der Stricht had written in July, 1919:

. . . we need your valuable support, for we will lose half of our subseribers, the Germans and Austrians. ... The Belgian government has not yet a penny available for laboratory work. In spite of all, we are very confident ... and Belgium, with the support of the States, will live again.

The use of the cytological preparations for purposes of securing funds was, of course, not thought of by their maker, but seemed quite legitimate to us. This communication in SCIENCE is thus intended as an informal report to the considerable number of institutions who cooperated by their orders as to the outcome of the scheme.

$\mathrm{Up}$ to the present time two remittances have been sent, totalling $\$ 350$. At the prevailing rate of exchange this allowed a realization of 4703 francs.

In the letters accompanying the remittances the liberty was taken of using the following wording, in part:

You must accept this small sum as being the result of your own labor. Incidentally you may well feel that you have assisted instruction as given in numerous American institutions; for not only in courses dealing with embryology and heredity, but also in all introductory courses in general biology the phenomena of maturation, fertilization and cell division constitute fundamental information ... much eredit is due the institutions which purchased the lantern slides, for without their orders our little enterprise would have been a failure.

In acknowledgment Professor Van der Stricht said, in part:

In agreement with my colleague, Dr. Brachet, we gratefully accept this amount which will be devoted to the publication of the Archives de Biologie. The cost of issuing this journal is, indeed, very great just now. Subseriptions do not cover it, so that we lose a great deal of money. Fortunately, my appeal in 1919 to the United States colleagues (for subseriptions) has been rather gratifyingly answered; many orders for sets came in, so that we were able to continue printing. Your ... donations will help us very much for this purpose. Thus we owe our " Zoological Friends in America " an immeasurable debt of gratitude.

I would like to add that sets of these lantern slides may still be obtained, though we are not making them except on receipt of orders. They clearly illustrate twelve important steps in maturation, fertilization, and the first cleavage of the eggs of Nereis limbata. The price is $\$ 15$ for the twelve slides, and the mutual agreement is that all receipts above actual expenses shall go for the assistance of Belgian science in the manner above indicated.

$$
\begin{aligned}
& \text { Robert A. Budington } \\
& \text { Spear laboratory, Oberlin College, } \\
& \text { Oberlin, Ohio }
\end{aligned}
$$

\section{THE VIBRATIONS OF A TUNING FORK}

To the EDITOR of ScIEnce: In a number of ScIEnce, ${ }^{1}$ which has just come to our attention, Professor Charles K. Wead makes the following statement:

In a recent article in a psychological journal the tuning fork is considered as composed of two bars each attached at one end to a solid block.

He then proceeds to describe Chladni's theory of the tuning fork to correct this "surprising" disclosure.

After reading Professor Wead's note we referred to our original paper. ${ }^{2}$ In comparing vibrating bars and forks we write:

The bar is, in fact, a fork straightened out; or, which is the same thing, the fork is a bar bent into the shape of a U. If we gradually bend a bar into a U, the two nodes approach the base. When the bending is complete we have a single node at the base-i.e., a fork.

Our point, of course, is that the tuning fork is essentially a bar-a single vibrating system.

1 Nov. 11, 1921, 468-9.

2 Psychological Bulletin, September, 1918, $293 \mathrm{f}$. 
Nowhere do we regard the fork as made up of two bars attached to a solid base. Since the question of how we may best regard a vibrating tuning fork has been raised, we have turned once more to Rayleigh. ${ }^{3}$ After a mathematical discussion he writes:

$\therefore$ These laws find an important application in the case of tuning forks, whose prongs vibrate as rods, fixed at the ends where they join the stalk, and free at the other ends.

Also Edwin H. Barton, ${ }^{4}$ a pupil of Lord Rayleigh, writes:

The behavior of the U-shaped bars just dealt with approximates to that of tuning forks. But the vibration of tuning forks is usually further complicated by the presence of an additional block at the center of the bend and the stem attached thereto. Indeed, it may be a nearer approximation to regard each prong as a straight bar fixed at the end near the stem and free at the other end.

It appears, then, that this "crude" manner of considering a tuning fork, which has been wrongly attributed to us, is actually accepted by no less an authority than Rayleigh and his pupil, Barton.

Profesor Wead's interpretation of our view is probably based upon our statement that the fork has a single node at the base. This, of course, is only an approximation.

An alternative explanation, according to Professor F. R. Watson, of this university, is to consider the fork as a single vibrating system in which the center of mass tends to remain fixed in position. As the tines of the fork are bending outward, the center of mass tends to lower, so that the stem and block of the fork rise a bit so as to keep the posi.tion of the center of mass unchanged. As the tines return inward, the center of mass tends to rise, so that the stem of the fork lowers. The stem of the fork thus executes minute up and down movements.

Paul Thomas Young

UNIVERSITY OF ILLINOIS

AN ANECDOTE CONCERNING DR. FIELD

I HAVE read with great interest Dr. Ward's sketch of the life and work of the late Herb-

3 “" Theory of Sound," 1894, Vol. I., 274.

4 " A Text-Book on Sound," 1908, 298. ert Haviland Field. It, however, omits any mention of his appreciation of humor, and perhaps I may be allowed to tell of one of his practical jokes which, to me at least, was most amusing.

The late Henry B. Pollard had just completed his work on the anatomy of Polypterus and had gone from Wiedersheim's laboratory for lunch. I came in a little later, started my studies, and then Pollard came in, and in a moment I realized what " Uncle Toby" meant when he referred to the profanity of "cur army in Flanders." Pollard turned to me, holding up a drawing of the cranial nerves of that fish which was almost completely covpered with hæmatoxylin, and demanded who did it. I knew nothing of it and so replied. Pollard said he would call the attention of the professor (Wiedersheim) to it and at once left the room. As he went out of one door of the laboratory, the door from the anatomical museum opened and in came Field, who removed the damaged drawing from Pollard's table, opened a drawer and took out another drawing, and again left the room. Pollard almost immediately returned, bringing the professor with him. "Look at that!" said Pollard. "Was ist los?" asked Wiedersheim, and then Pollard looked and saw his drawing in perfect condition. I never saw such an expression of complete inability to comprehend as that on Pollard's face. He was utterly without words, The explanation of the whole was that Field had found the tracing paper which Pollard had used, had rapidly redrawn on another sheet the nerves and skull of Polypterus, had deluged it with staining fluid and left it for Pollard to find, waiting in the museum to hear what the English youth would and could say.

\section{S.}

\section{TWO RETROSPECTIVE FEATURES OF THE TORONTO MEETING}

THE membership list in the last volume of the Summarized Proceedings, recently published, shows that the Association has a considerable number of members living in coun- 